\title{
VÝSLEDKY PRIESKUMU UPLATNENIA ABSOLVENTOV KATEDRY SPOJOV, KTORÍ UKONČILI INŽINIERSKE ŠTÚDIUM V JÚNI 2007 V ODBOROCH POŠTOVÉ TECHNOLÓGIE A POŠTOVÉ SLUŽBY
}

\author{
Zuzana Hnatová, Jana Palková, Iveta Kremeňová *
}

Poslaním vysokých škôl je rozvíjat' harmonickú osobnost', vedomosti, múdrost', dobro a tvorivost' $\mathrm{v}$ človeku a prispievat' $\mathrm{k}$ rozvoju vzdelanosti, vedy, kultúry a zdravia pre blaho celej spoločnosti. Napíňanie tohto poslania je predmetom hlavnej činnosti vysokých škôl.

Katedra spojov, Fakulty prevádzky a ekonomiky dopravy a spojov, Žilinskej univerzity $\mathrm{v}$ Žiline, je profilovou katedrou pre výchovu vysokoškolsky vzdelaných odborníkov pre prevádzku a ekonomiku subjektov pôsobiacich na info - komunikačných trhoch $\mathrm{v}$ rámci študijných odborov Poštové technológie a Poštové služby. Absolventi sú pripravovaní na riadenie obchodných a ekonomických činností na rôznych organizačných stupňoch podniku.

V školskom roku 2006/2007 úspešne ukončilo denné štúdium 41 študentov v študijnom odbore Poštové služby a 19 študentov v študijnom odbore Poštové technológie. Aby univerzita získala obraz o úspešnosti svojej činnosti a aby zistila a mohla odstránit' svoje nedostatky, každoročne realizuje prieskum zameraný na uplatnenie svojich absolventov v praxi. O výsledkoch tohto prieskumu sa dočítate v tomto článku.

\section{Zhodnotenie výsledkov prieskumu}

Prieskum bol realizovaný v mesiacoch október a november 2007, teda 4 až 5 mesiacov po ukončení štúdia. Absolventi boli kontaktovaní študijným oddelením fakulty, prostredníctvom zaslaného dotazníka na domácu adresu a bola využitá aj metóda elektronického dopytovania respondentov. Boli oslovení všetci 60-ti absolventi denného štúdia Katedry spojov. Návratnost' dotazníkov predstavuje za odbor Poštové technológie $63,2 \%$ a za Poštové služby $68,3 \%$.

Celková návratnost' dotazníkov realizovaného prieskumu je $66,7 \%$, čo je najviac v porovnaní s prieskumami uplatnenia absolventov realizovanými v minulosti. Posledný prieskum uplatnenia absolventov v praxi bol uskutočnený v roku 2005, kedy odpovedalo na

\footnotetext{
*Ing. Zuzana Hnatová, Ing. Jana Palková, Doc. Ing. Iveta Kremeňová, PhD., Katedra spojov, F-PEDAS, Žilinská univerzita v Žiline, Univerzitná 1, 01026 Žilina tel.: +421415133144, fax: +421415655615 e-mail: Zuzana.Hnatova@fpedas.uniza.sk
} 
dotazník 38,6 \% respondentov. V roku 2004 bolo zaznamenaných 56,0 \% odpovedí, v roku $200314,4 \%$ a $25,5 \%$ v roku 2002.

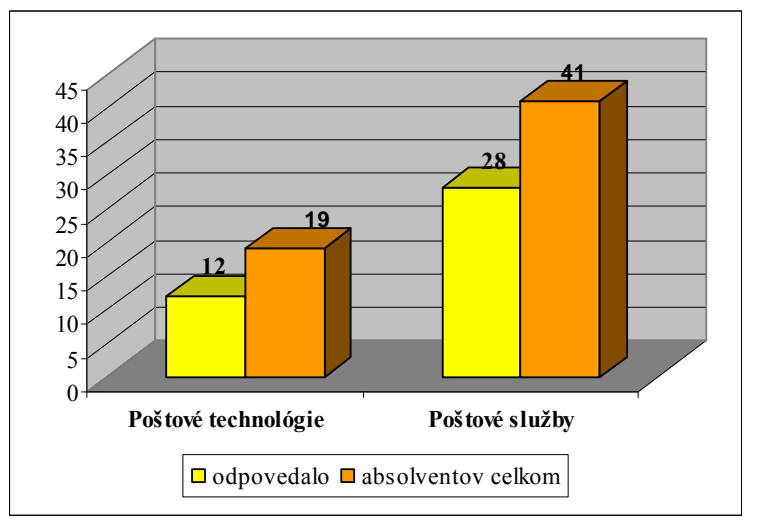

Obrázok 1 Návratnost’ dotazníkov v roku 2007

\section{a) Zamestnanost' absolventov}

Z oslovených respondentov, ktorí odpovedali na dotazníky, je 30 zamestnaných a 10 sú nezamestnaní. To znamená, že $75 \%$ našich absolventov si už po 4-5 mesiacoch po ukončení štúdia našlo trvalé zamestnanie, čo môžeme hodnotit' vel'mi pozitívne. Zamestnanost' podl'a jednotlivých študijných odborov je uvedená na obrázku 2.

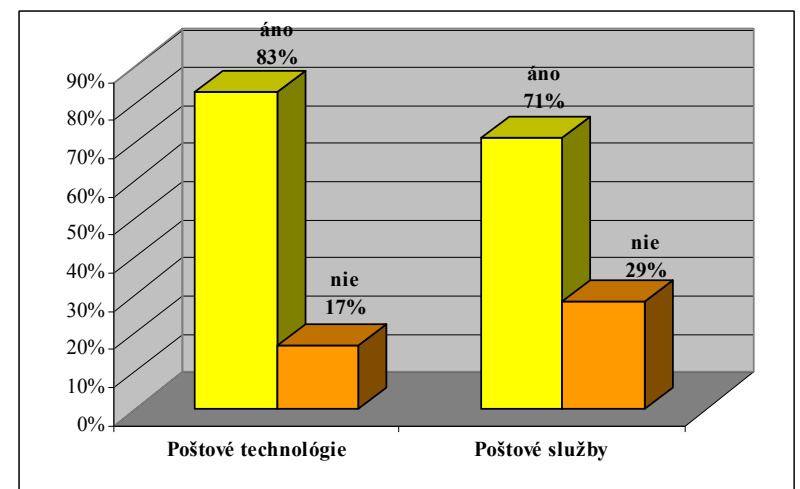

Obrázok 2 Odpoved’ na otázku: „Máte v súčasnosti trvalé zamestnanie?“‘

Hned' po ukončení školy sa zamestnalo 29 \% respondentov študijného odboru Poštové služby, čo súviselo aj s ich pracovnými aktivitami už počas štúdia. V odbore Poštové technológie si $33 \%$ absolventov zúčastnených na prieskume našlo zamestnanie do 2 mesiacov. Ako je možné vidiet' na obrázku 3;8\% absolventov odboru Poštové technológie a $11 \%$ absolventov odboru Poštové služby je v súčasnosti nezamestnaných. Napriek tomu na otázku: „Máte v súčasnosti trvalé zamestnanie?“" (obrázok 2) záporne odpovedalo $17 \%$ respondentov z odboru Poštové technológie a 29 \% z odboru Poštové služby. Tento rozdiel je spôsobený tým, že niektorí z absolventov vykonávajú absolventskú prax alebo dočasne pracujú v zahraničí. 


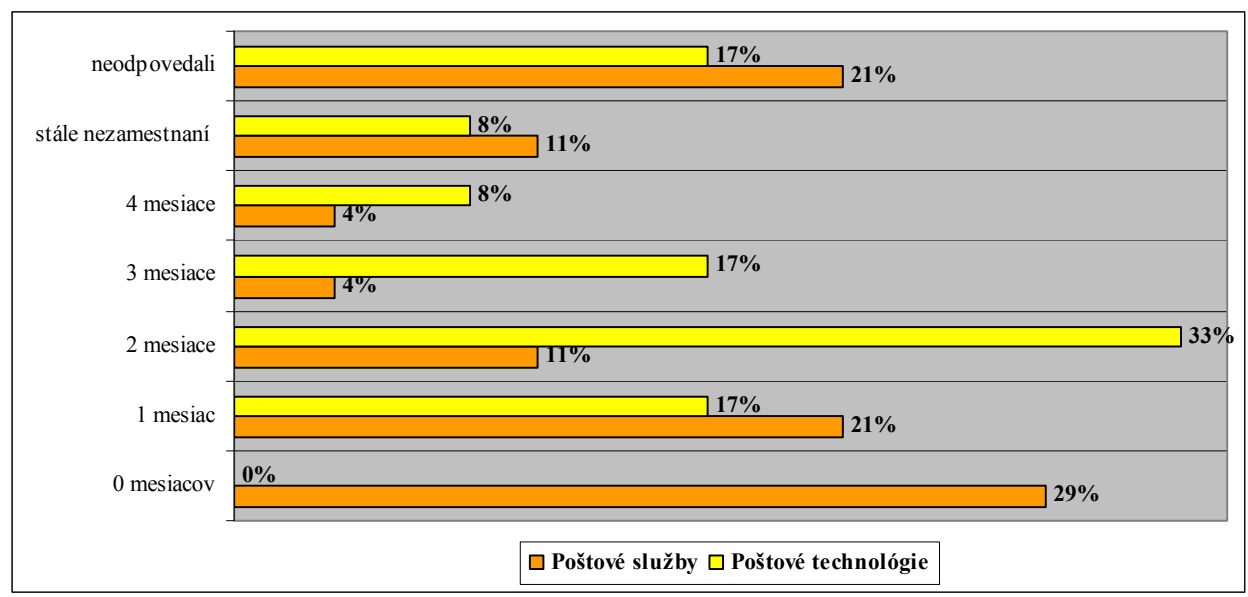

Obrázok 3 Odpoved’ na otázku: „Boli ste zamestnaný (ako dlho)?““

Uplatnenie absolventov v odbore štúdia, ktoré znázorňuje obrázok č. 4, je $11 \%$. Tento počet z roka na rok klesá. V roku 2005 to bolo $20 \%$, v roku 2004 to bolo až $41 \%$. Súvisí to aj s tým, že respondenti, ktorí odpovedali na dotazník, si s touto otázkou stotožňovali vo väčšine prípadov iba zamestnanie v sektore pôšt a nebrali do úvahy možnost' zamestnania sa v oblasti logistiky a siet'ových podnikov.

Realizovaný prieskum ukázal, že absolventi odboru Poštové technológie majú vyššie zastúpenie uplatnenia v odbore štúdia v praxi ako absolventi odboru Poštové služby. Štvrtina (3 respondenti) absolventov odboru Poštové technológie našla uplatnenie v odbore štúdia. Spomedzi absolventov štúdia Poštové služby sa v odbore uplatnil len jeden absolvent, čo predstavuje $4 \%$ z celkového počtu absolventov, ktorí na dotazník odpovedali.

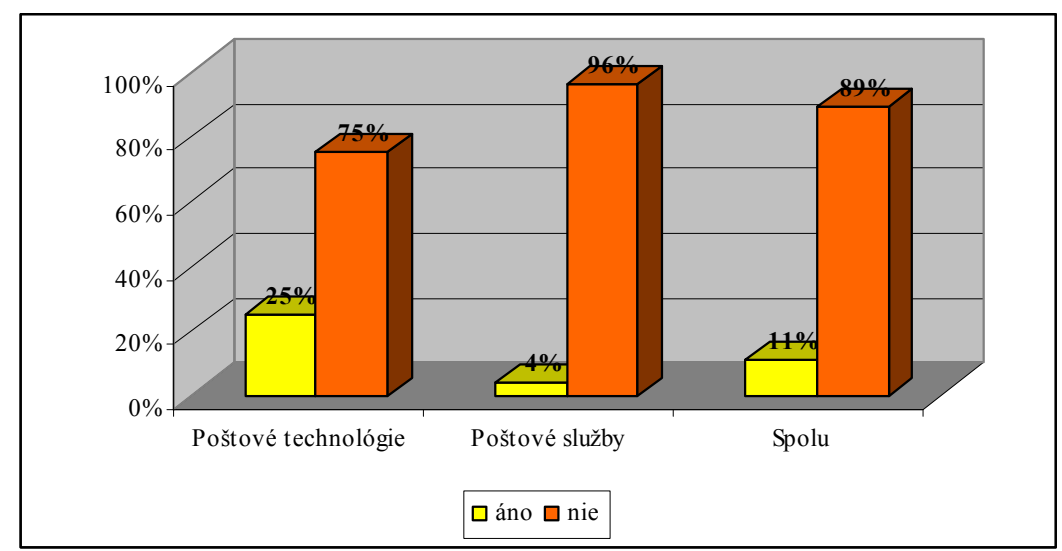

Obrázok 4 Odpoved' na otázku „Pracujete v odbore, v ktorom ste vyštudovali?““

Z hl’adiska inštitúcií, ktoré zamestnávajú našich absolventov, patria medzi najväčších zamestnávatel'ov inštitúcie pôsobiace $\mathrm{v}$ oblasti finančného poradenstva, telekomunikácií, inštitúcie pôsobiace voblasti logistiky, informačných technológií, poist'ovníctva a internetovej reklamy. Podrobná skladba oblastí, v ktorých našli naši absolventi zamestnanie je znázornená na obrázkoch 5 a 6 . 


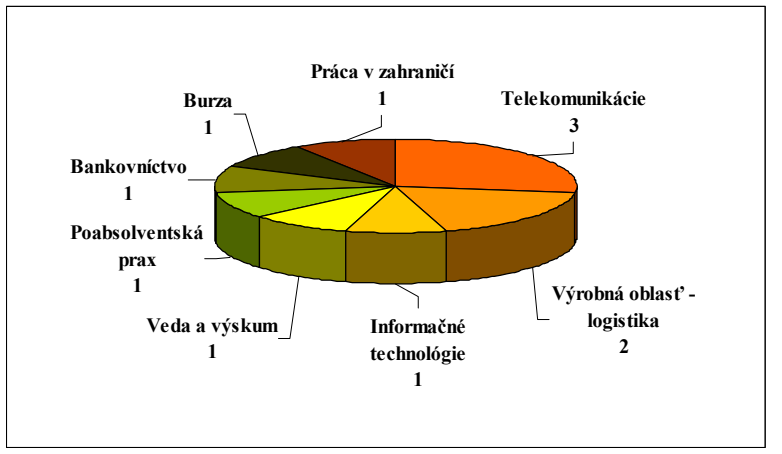

Obrázok 5: Odpoved' na otázku ,Vaše súčasné pracovné zaradenie, odbor činnosti, funkcia“" Poštové služby

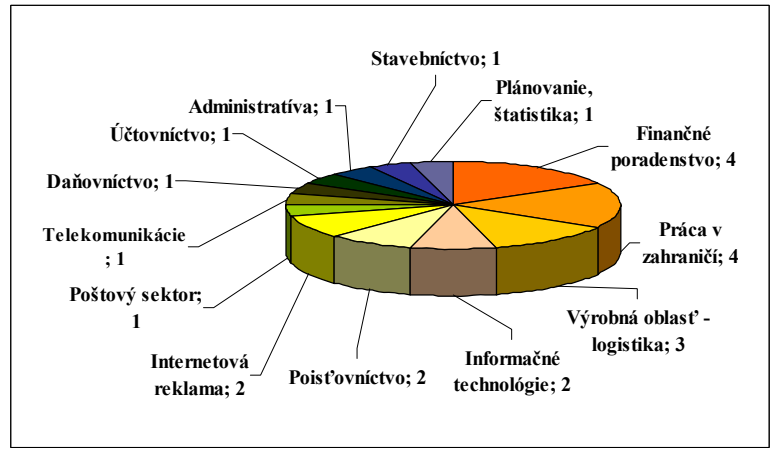

Obrázok 6: Odpoved' na otázku „Vaše súčasné pracovné zaradenie, odbor činnosti, funkcia“" Poštové technológie

Vzhl'adom na krátkost' obdobia realizácie prieskumu od skončenia štúdia respondentov sú tieto výsledky dôkazom toho, že aj ked' absolventi nenájdu uplatnenie v odbore štúdia, vedia sa prispôsobit' trhovým podmienkam a nájst' si trvalé zamestnanie v iných, resp. príbuzných odvetviach.

\section{b) Využitie poznatkov}

Ďalšou skúmanou oblast’ou bolo využívanie získaných poznatkov počas štúdia v praxi. Implementácia získaných poznatkov v praxi je vel'mi nízka. Najviac respondentov na otázku: „Uplatňujete získané poznatky z vysokej školy?“ odpovedalo, že získané poznatky uplatňuje čiastočne (64 \% z odboru Poštové služby, $42 \%$ z odboru Poštové technológie). 32 \% respondentov z odboru Poštové služby a $42 \%$ z odboru Poštové technológie vôbec neuplatňuje získané poznatky a $4 \%$ absolventov odboru Poštové služby a $17 \%$ absolventov odboru Poštové technológie získané poznatky v praxi uplatňuje. Je dôležité uviest', že respondenti odpovedali na položenú otázku krátko po nástupe do praxe a bolo ju teda t'ažké zodpovedat', ked'že sa ešte takmer všetci zaúčali v skúšobnej dobe. Kol'ko percent získaných poznatkov z vysokej školy naši absolventi využívajú sa dozviete z obrázku 7. Pre lepšiu vypovedaciu schopnost' sú v obrázku uvádzané počty odpovedí respondentov.

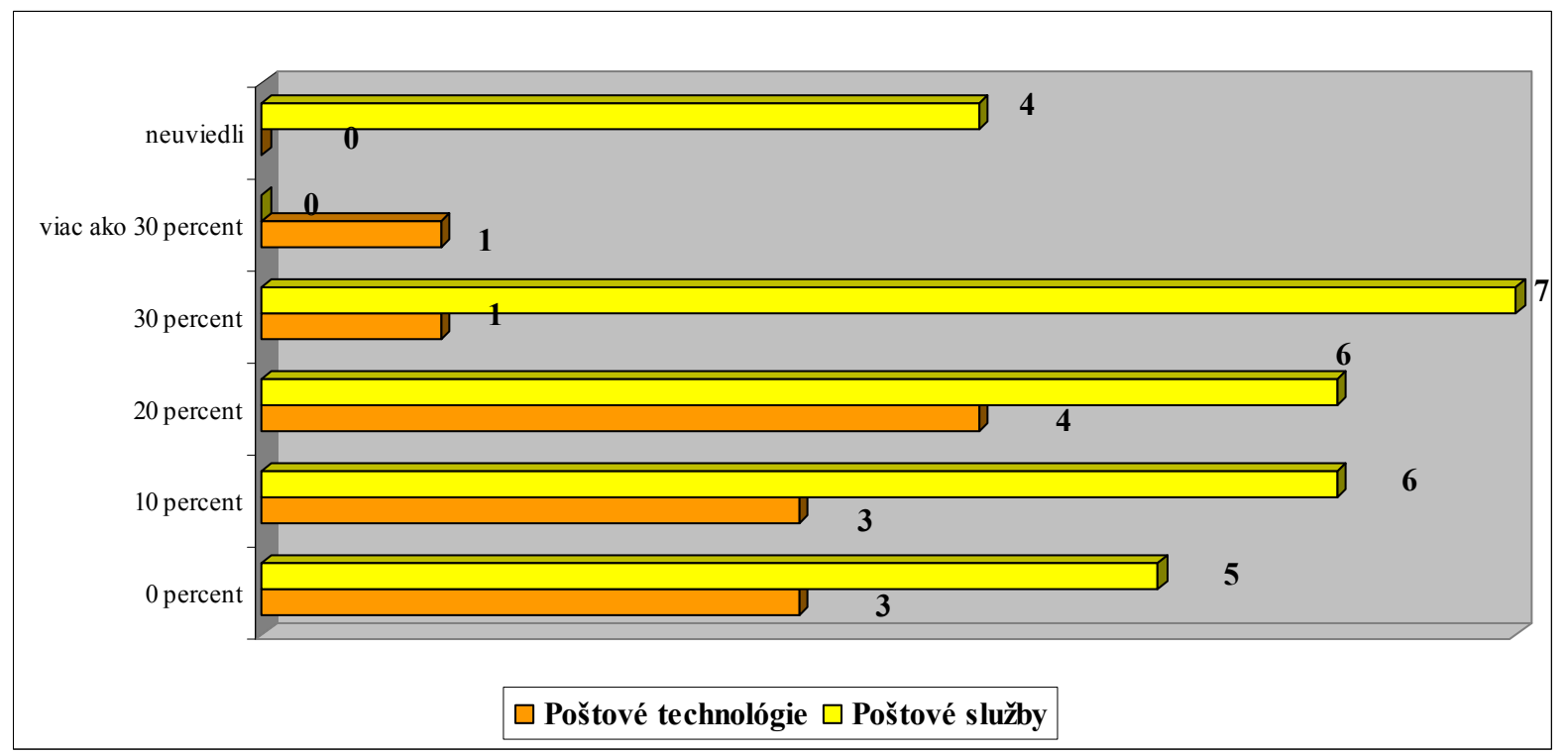

Obrázok 7 Odpoved' na otázku: „Kol’ko percent získaných poznatkov z vysokej školy uplatňujete v praxi? 
Aby škola mohla zvýšit' počet študentov, ktorí získané vedomosti využívajú v praxi ako aj percento uplatňovaných poznatkov v praxi, zist'ovali sme tiež, poznatky ktorého predmetu absolventi najčastejšie uplatňujú v praxi. Výsledky nášho prieskumu sú uvedené na obrázkoch 8 a 9 pre jednotlivé odbory. Sú tu uvedené predmety, ktoré uviedli minimálne dvaja respondenti. Mnohé d’alšie predmety „obdržali“ len po jednom hlase. Zaujímavé je, že sa v tejto skupine predmetov objavujú aj predmety, ktoré by mali tvorit' len doplnok štúdia, ako napríklad Matematika a Fyzika. Vyplýva to z toho, že až 89 \% absolventov nepracuje v odbore, ktorý vyštudovali.

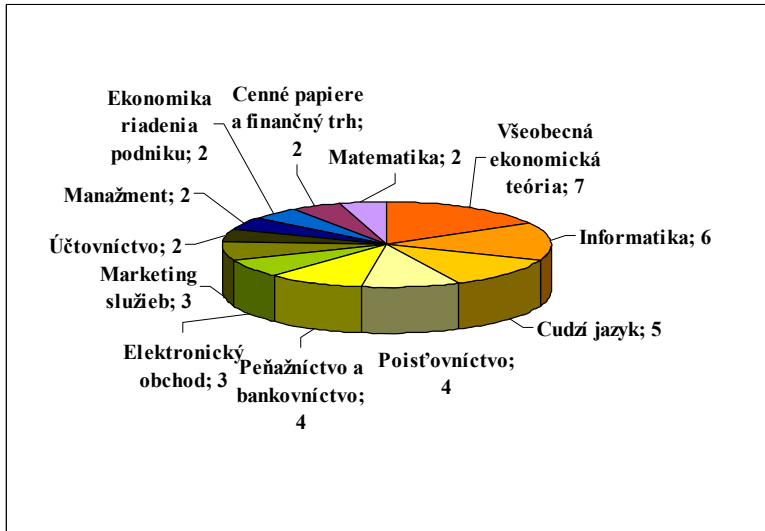

Obrázok 8 Odpoved’ na otázku: „Poznatky ktorého predmetu najviac využívate v praxi?“" Poštové služby

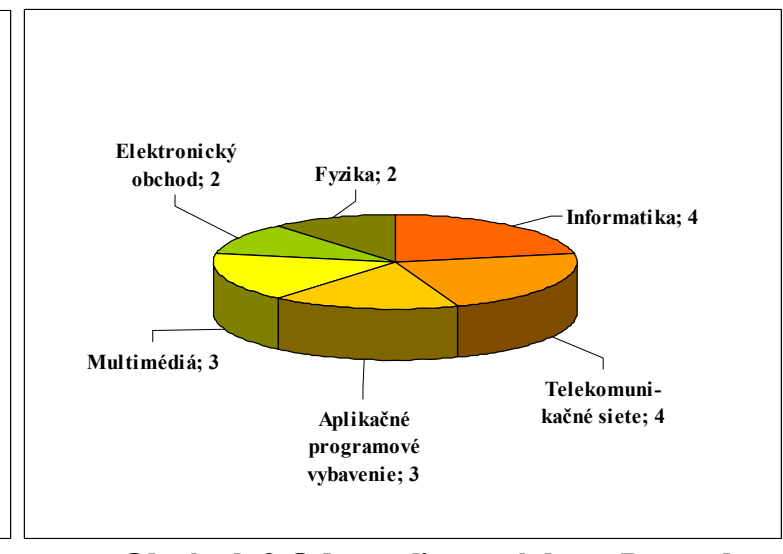

Obrázok 9 Odpoved’ na otázku: „Poznatky ktorého predmetu najviac využívate v praxi?" Poštové technológie

Zaujímalo nás tiež, poznatky ktorého predmetu naši absolventi v praxi najmenej využívajú. Obdobne ako pri predchádzajúcej otázke, nie sú uvedené všetky predmety, mnohé dostali po jednom hlase. Chceme však upozornit' na fakt, že respondentom nebol poskytnutý zoznam predmetov, ktoré absolvovali, čo mohlo do značnej miery ovplyvnit' ich výber. Nespomenuli si na všetky. Na druhej strane je možné aj to, že respondenti uvádzali len tie predmety, ktoré im napadli ako prvé, ked’že s ich absolvovaním mali problémy. Výsledky sú znázornené na obrázkoch 10 a 11. Výraznou skupinou nepouživaných predmetov u obidvoch odborov sú predmety zamerané na poštu, vrátane technológie a mechanizácie. Opät' to súvisí s oblast’ami, v ktorých naši študenti našli uplatnenie.

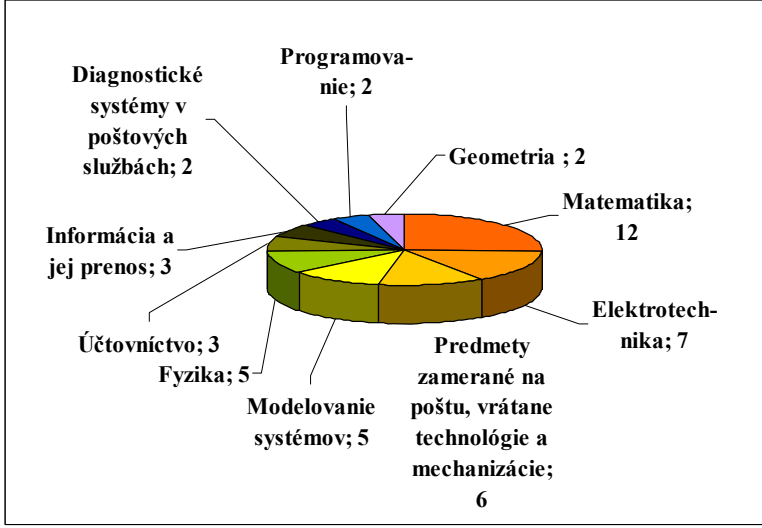

Obrázok 10 Odpoved’ na otázku: „Poznatky ktorého predmetu najmenej využívate v praxi?““ - Poštové služby

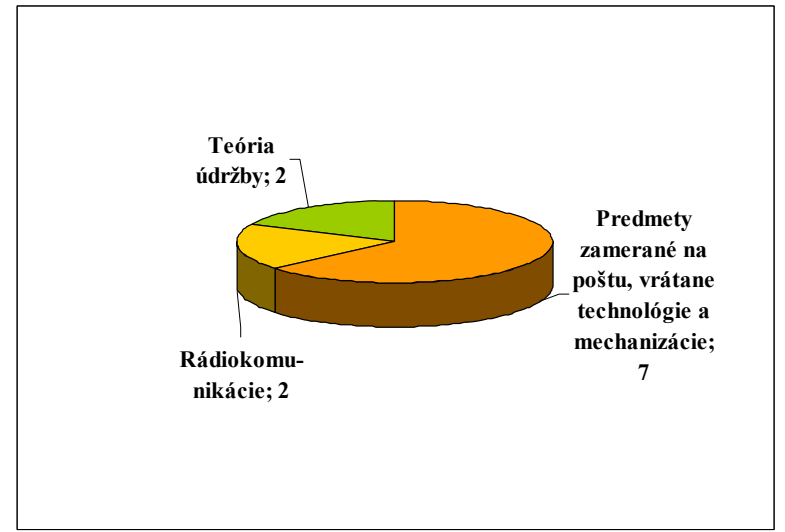

Obrázok 11 Odpoved' na otázku: „Poznatky ktorého predmetu najmenej využívate v praxi?" Poštové technológie 


\section{c) Hodnotenie absolvovaného štúdia}

Posledná otázka v dotazníku sa venovala konkrétnym návrhom na zaradenie nových predmetov do študijných programov, resp. doplnenie nových oblastí, ktoré chýbajú v aktuálnych programoch. V dotazníkoch prevládala požiadavka na doplnenie vzdelania cudzích jazykov a financií. V minulých rokoch sa objavovali požiadavky na prepojenie teórie s praxou a doplnenie poznatkov z informatiky a tiež cudzích jazykov.

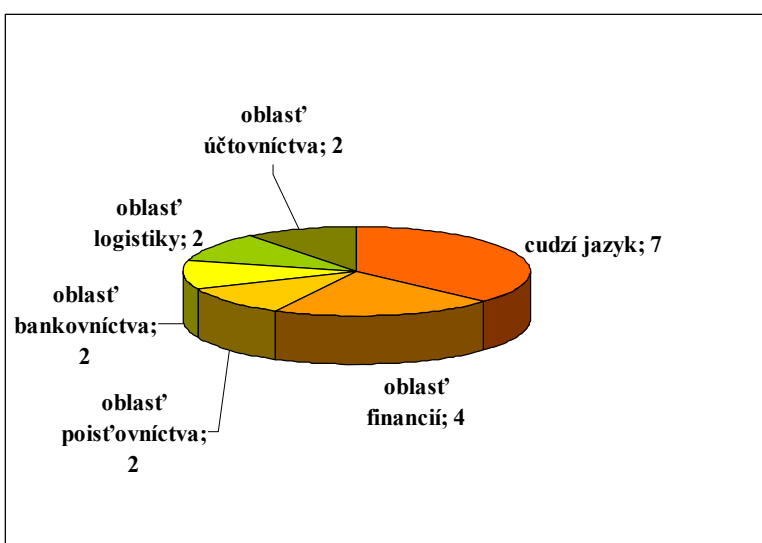

Obrázok 12 Odpoved' na otázku: „Z akej oblasti poznania by ste si potrebovali doplnit' svoje poznatky pre výkon terajšieho zamestnania?" Poštové služby

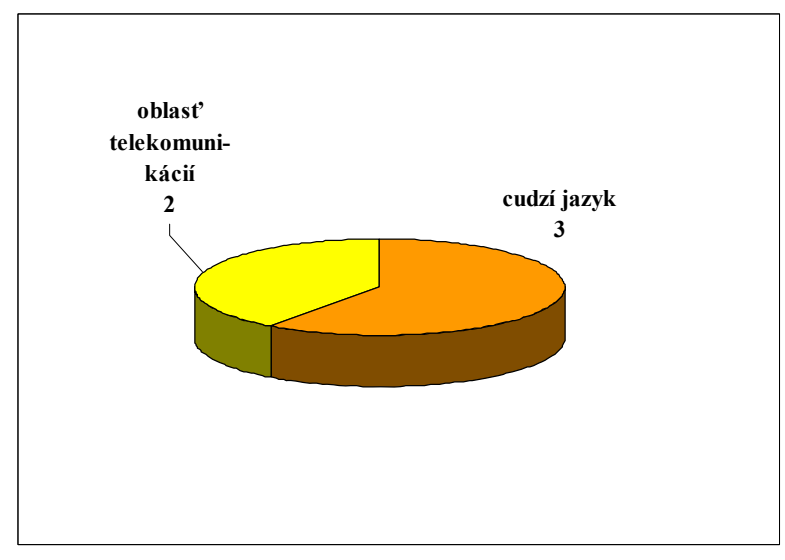

Obrázok 13 Odpoved’ na otázku: „Z akej oblasti poznania by ste si potrebovali doplnit' svoje poznatky pre výkon terajšieho zamestnania?" Poštové technológie

\section{Záver}

Ukončením štúdia v odboroch Poštové služby a Poštové technológie sa môžu absolventi uplatnit' $\mathrm{v}$ niektorých profesiách $\mathrm{v}$ poštovej prevádzke, či už na poštách alebo $\mathrm{v}$ podnikoch pôsobiacich nielen na poštových a telekomunikačných trhoch ale aj v logistických a siet'ových podnikoch, $v$ úradoch štátnej správy a finančných a obchodných organizáciách. Uplatnenie absolventa $\mathrm{v}$ praxi je získanie zamestnania na úrovni operatívneho riadenia. A nielen v pošte, ako naznačujú názvy študijných odborov. Vyplývajúc z obsahu absolvovaných predmetov je možné uplatnenie tiež $\mathrm{v}$ telekomunikáciách, $\mathrm{v}$ bankových, finančných a poist'ovacích inštitúciách. Realizácia je možná aj v oblasti využívania informačných technológií a logistických riešení. V prípade založenia vlastného podniku by absolventi mali byt' schopní riadit' malú a strednú firmu v oblasti služieb.

Ako vidiet' $\mathrm{z}$ výsledkov prieskumu, uplatnenie našich absolventov je rôznorodé. Väčšina respondentov si našla svoje miesto v inštitúciách pôsobiacich v oblasti financií, poist'ovníctva, logistiky, informačných technológií, telekomunikácií a internetovej reklamy. Potešujúci je fakt, že $75 \%$ respondentov si našlo zamestnanie už po 4-5 mesiacoch od ukončenia štúdia, čo svedčí o tom, že naši absolventi sú dobre pripravení pre prax. 